\title{
Viagens aos Infernos: A experiência visionária como ensaio para uma filosofia pré e pós humanista
}

\author{
Journeys to Hells: The visionary experience as an essay of a philosophy pre and post \\ humanism
}

Tiago Brentam Perencini*

Resumo: Por que a experiência visionária perturba a filosofia (crítica)? Experimentando uma
anarqueologia como procedimento de leitura, argumento que a relação entre filosofia e magia
no curso da história ocidental pode ser encenada como uma peça paradoxal. Da mesma
maneira que a filosofia racionalista conjura a magia, simultaneamente, tais saberes estiveram
presentes de modo polifônico nos bastidores da encenação ilustrada. Evoco o itinerário das
viagens aos infernos ao qual certa visão xamanística de alma grega fecunda possibilidades
para ensaiarmos um tipo de filosofia pré e pós crítica, onde a experiência visionária aparece
posteriormente como pedra no sapato ao pensamento ilustrado, científico e humano.
Exemplifico tal questão recorrendo à visão paradoxal de Immanuel Kant quando analisa as
experiências visionárias de Emmanuel Sweadenborg. Ao reconhecer contemporaneamente a
nossa herança legítima como filhos da razão, será preciso reencarnar o lugar bastardo dos
sonhos e da mediunidade exorcizada. Palavras-chave: Experiência Visionária; Sonhos; Humanismo, Michel Foucault; Swedenborg; Kant.

\begin{abstract}
Why does the visionary experience disturb philosophy (critique)? Experimenting with anarchaeology as a reading procedure, I argue that the relation between philosophy and magic throughout Western history may be staged as a paradoxical play. Just as rationalist philosophy invokes magic, simultaneously, such knowledges were present in a polyphonic way in the wings of the illustrated staging. I evoke the itinerary of the journeys to hells to which such shamanistic view with greek soul fecundates possibilities to rehearse a type of philosophy beyond critique, in which the visionary experience appears afterwards as a thorn in the side of illustrated, cientific and human thought. I exemplify such matter resorting to Immanuel Kant's paradoxical view while he analyzes the visionary experiences of Emmanuel Swedenborg. In contemporaneously acknowledging our legitimate heritage as children of the reason, it may be needed to reincarnate the bastard place of dreams and mediumship exorcized.
\end{abstract}

Keywords: Visionary Experience, Dreams, Humanism, Michel Foucault, Swedenborg, Kant.

\section{Uma experimentação anarqueológica}

Os saberes, práticas e subjetividades oriundas da magia têm ressoado com uma força irruptiva em nosso tempo presente. Parte de minha trajetória existencial e de pesquisa tem sido dedicada ao resgate de certa interface "esquecida" entre filosofia e magia. 0 pensamento mágico com o qual dialogo se insere mais diretamente na chave aberta pelo pósestruturalismo e pela filosofia da diferença em sua crítica ao humanismo, procurando repensar o discurso filosófico por outras frentes. Mais precisamente, o meu doutoramento ${ }^{1}$ possibilitou-me apontar que retomar a história arcaica do cuidado de si - pensando com e para além daquilo que Michel Foucault nos permitiu caminhar por esse campo conceitual -

1 PERENCINI, Educação, filosofia e magia: uma anarqueologia do cuidado de si entre o daimon e os sonhos.

* Doutorando em Filosofia e História da Educação no Brasil, pelo Programa de Pós-Graduação em Educação da Universidade Estadual Paulista Júlio de Mesquita Filho, Marília, SP tiagobrentam@gmail.com ORCID: https://orcid.org/0000-0001-77424387-4387 
sugere estabelecermos um diálogo com a força erótica da magia, relação com o conhecimento eclipsada pelas estruturas científicas e humanas que vigoram em nossa formação acadêmica e filosófica no tempo presente, silêncio que parece se confundir com a própria emergência do Ocidente e da história da filosofia ocidental.

Como contribuição para esse instigante dossiê, que nos incita a refletir acerca dos desafios atuais para o pensamento sobre as ciências e suas interfaces desde uma perspectiva filosófica, procurarei refletir acerca da seguinte problemática: por que a experiência visionária perturba a filosofia (crítica)? Entendo por experiência visionária uma maneira de conhecer o mundo habitado pelo paradigma onírico, calcado na intuição e na imaginação como possibilidade de enunciação de outros mundos e modos de vida alinhados ao dom da (clari)vidência, relação articulada ao universo da magia e do esoterismo em inscrições tais como o xamanismo, a feitiçaria, a profecia, etc. Experimentando uma anarqueologia aos moldes foucaultianos como procedimento de leitura, argumento que a relação entre filosofia e magia no curso da história ocidental pode ser encenada como uma peça paradoxal. Se, por um lado, a filosofia racionalista em nada se evadiu do círculo de poder que conjurou e demonizou os saberes mágicos, por outro e simultaneamente, a magia esteve presente de maneira polifônica nos bastidores da encenação ilustrada. Evoco o itinerário das viagens aos infernos (catábases) ao qual certa visão xamanística de alma grega fecunda possibilidades de pensarmos um tipo de filosofia para aquém e além da crítica, onde a experiência visionária aparece como pedra no sapato ao pensamento ilustrado, científico e humano. Procuro, com tal evocação, pensar para além de uma concepção racional de filosofia crítica, reconhecendo a magia como presença (in)desejável em diferentes momentos do discurso filosófico, resgatando particularmente a visão paradoxal de Immanuel Kant quando analisa o pensamento esotérico e as experiências visionárias de Emmanuel Swedenborg, vidente sueco, objeto concomitante de incômodo e fascínio para o arcabouço crítico da razão. Não será difícil perceber que o esoterismo se tece como uma prática filosófica à sombra do iluminismo e, posteriormente, também das ciências humanas.

Meu olhar é orientado desde uma perspectiva foucaultiana, pensando com e para além do que o pensador francês nos permitiu investigar sobre a questão. Foucault (2014) dedica-se à anarqueologia dos saberes no curso Du gouvernement des vivants - Do Governo dos vivos, proferido no Collège de France em 1980. A primeira menção que faz da anarqueologia aparece na Aula de 30 de janeiro de 1980. A referência é enunciada, primeiramente, sem os parênteses: "Então eu lhes direi que o que lhes proponho seria antes uma espécie de anarqueologia"2. Já na aula conseguinte, de 6 de fevereiro de 1980, Foucault a utiliza entre parênteses, sugerindo a relação viva com a arqueologia: “... direi que fazer a arqueologia ou a (an)arqueologia do saber não seria, portanto, estudar de maneira global as relações do poder político com o saber ou com os conhecimentos científicos" 3 . 0 termo encontra proximidade com a obra Contra o método, do filósofo austríaco Paul Feyrabend 4 , que Foucault cita de maneira curiosa, entre parênteses: "(Dito isso, entre parênteses, se vocês quiserem ler livros interessantes de filosofia que saem atualmente - são tantos -, recomendo em vez de outros mais barulhentos, [o] de Feyerabend que acaba de sair pela Seuil sobre a ciência. Ninguém fala dele, mas, sobre o problema anarquia e saber, está aí uma coisa interessante)"5. Ora, sabemos que Feyerabend propõe um anarquismo epistemológico, afirmando que a ciência é um empreendimento essencialmente anarquista, e por isso mesmo nos alerta para os limites de qualquer metodologia, isto é, para os limites da razão científica, dos raciocínios lógicos.

\footnotetext{
2 FOUCAULT, Do governo dos vivos, 73.

${ }^{3}$ FOUCAULT, Do governo dos vivos, 91.

4 FEYERABEND, Contra o método.

${ }^{5}$ FOUCAULT, Do governo dos vivos, 72.
} 
Pensando para além dos limites da razão científica, tenho experimentado uma anarqueologia enquanto procedimento de pesquisa, que sugere tomar os enunciados presentes no percurso existencial foucaultiano como cotejo de palavras cruzadas, indicando que a busca por relações com a verdade implicada em outras formas de vida estaria presente desde a produção protoarqueológica do jovem Foucault, paralela ao legado tardio de seus cursos de maturidade no Collège de France, além de entrevistas heterodoxas pouco visíveis pela comentografia geral. A busca por arquivos heterodoxos no pensamento de Michel Foucault tem correspondido ao que Alexandre Simão de Freitas ${ }^{6}$ vem chamar de corpus vaporoso, ou legado tardio em seu pensamento.

Faz parte desse legado um conjunto de textos aparentemente heterogêneo, como suas reportagens sobre o Irã, suas aulas nos cursos finais no Collège de France, suas análises sobre a questão do Esclarecimento e o problema da revolução, mas principalmente a redescoberta dos seus textos chamados protoarqueológicos.

Seguindo Freitas, "esse corpus vaporoso permite colocar em outras bases o interesse de Foucault pela Antiguidade greco-romana, explicitando não apenas sua autovinculação paradoxal a Kant, mas, sobretudo, delimitando o lugar da espiritualidade nos seus últimos escritos"7. Pesquisadores dedicados a esse legado ${ }^{8}$ têm apontado uma continuidade assombrosa entre os escritos do jovem Foucault nos anos 1950 às análises desdobradas em sua fase ética, que vão de uma

'teoria geral do ser humano' a uma análise histórica das formas de experiência, o que permite perceber como o próprio Foucault se impôs a tarefa de recusar os humanismos e evitar as antropologias, sem, contudo, afastar da sua visada crítica o esforço para uma apreensão do homem em sua singularidade concreta 9 .

A maneira singular como uso a anarqueologia exige certa experimentação em face da própria anarqueologia foucaultiana, torcendo outras possibilidades interpretativas e inventivas que mais se alinhem à forma de enunciação de meu campo, articulado ao propósito desse dossiê, qual seja, a transversalidade entre filosofia e magia.

Relacionar, dessa maneira, os escritos do jovem ao tardio Foucault permite flertarmos a um movimento de transversalidade em face daquilo que foi produzido acerca desse autor, dois momentos distintos que se desaguam no sonho como eixo comum a ser esculpido entre $\operatorname{ambos}^{10}$. Tais momentos agenciam-se "curiosamente às voltas com a atividade onírica do

\footnotetext{
${ }^{6}$ FREITAS, Os perigos de uma ontologia política ainda sem cabimento ou o legado ético-espiritual de Michel Foucault, 11.

7 FREITAS, Os perigos de uma ontologia política ainda sem cabimento ou o legado ético-espiritual de Michel Foucault, 11.

${ }^{8}$ MIOTTO, O Problema Antropológico em Michel Foucault; NALLI, M. Possibilidades e limites da cura nos textos protoarqueológicos de Michel Foucault.

9 FREITAS, Os perigos de uma ontologia política ainda sem cabimento ou o legado ético-espiritual de Michel Foucault, 14.

10 É importante mencionar que o jovem Foucault, quando escreve em 1954 a Introdução a Sonho e Existência (2006b) de Ludwing Binswanger, vem encontrar no psiquiatra suíço - pioneiro na psicologia existencial, com roupagem da fenomenologia heideggeriana - as pistas para pensar o projeto de uma filosofia da expressão como ultrapassagem da fenomenologia. Ao mesmo tempo em que compreende os limites dessa abordagem, Foucault encontra nela a abertura para mostrar como a existência se realiza de maneira significativa no sonho. 0 Foucault tardio confere visibilidade a onirocrítica a partir do arquivo Sobre a Interpretação do sonho, de Artemidoro de Daldis (2009), texto que data do século II de nossa era e pode ser considerado a mais completa enciclopédia de onirocrítica no mundo antigo. Artemidoro recebe de Apolo, através de sonho, a missão de escrever esse livro, algo que cumpriu com muito afinco, afinal os sonhos são coisa muito séria para o mundo antigo. Foucault analisa esse arquivo no curso Subjetividade e verdade [1980-1981] (2016), mais precisamente na aula de 21 de janeiro
} 
espírito humano. Para os dois, o sonho seria um dos núcleos irradiadores de sentido da existência e uma chave de abertura das artes da existência mobilizadas pela analítica do cuidado de si"11, como certa alquimia a unir corpo e alma desde os sinais enviados pelo daimon, como procurei mostrar em outra oportunidade ${ }^{12}$. 0 trabalho de Foucault em concretizar uma filosofia da expressão que culminaria em uma ontologia decifrada em chave onírica não se viabilizava diretamente, muito embora seus escritos permitam pistas de que esse "projeto" se realizava como seu exercício espiritual em andamento, particularmente se tomarmos nota de que o campo ético desenvolvido em seus últimos cursos já se encontrava presente nos textos protoarqueológicos, do jovem Foucault. Com isso, figuras tão importantes em seu projeto filosófico, como o "si", já se encontravam desenvolvidas em germe.

A postura anarqueológica engloba a arqueogenealogia, mas possibilita a sua expansão porque sugere certa manifestação da verdade sobre a forma de subjetividade como arquivo vivo. Tomei por tarefa nessa direção a escavação em busca de modos de subjetivações que não se estabelecem desde as origens e as causas históricas. A especificidade de tal procedimento consiste em analisar a partir de que modos se procurou dizer a verdade sobre determinados sujeitos que impediram outros jogos na relação consigo mesmo e com os outros, buscando por formas de pensamentos que foram arrancadas pelos conhecimentos objetivos e racionais, atividade que também sugere fazer da história da subjetividade certa invenção.

\section{Viagens aos Infernos: o sonho como interface entre filosofia e magia}

Foucault sabe bem que o sonho é um princípio que poucas culturas ignoraram e, por isso, circulou ao longo de toda a história das relações entre subjetividade e verdade. "Quando está em causa fundar o acesso do sujeito à verdade, indagar sobre a verdade da verdade ou ainda buscar o que é a verdade do sujeito, de qualquer forma o problema, a temática dos sonhos reaparece"13 porque nos convocam a pensar o que fazer, na vigília, com essa parte obscura de nós mesmos que se ilumina à noite e da qual pouco temos controle.

Em termos filosóficos, segundo Foucault, o sonho abre espaço para a seguinte problemática, como descrito no curso Subjetividade e verdade:

A verdade da verdade é verdadeira? Não se poderia pensar que a verdade da verdade não é verdadeira, que na raiz da verdade há outra coisa além da própria verdade? E se a verdade só fosse verdadeira tendo como fundo [esse] enraizamento em algo que é como a ilusão e o sonho? E se afinal a verdade fosse apenas um momento de algo que é apenas sonho? (...) e não seria através do que há de mais manifestamente ilusório no sujeito que é dito o que é a verdade mais secreta do sujeito? (14grifo do tradutor).

Certo processo de subjetivação ocorre desde o sonho porque nele o sujeito experimenta uma relação com o mundo que não passa pela separação e antagonismo entre sujeito e objeto, eu e o outro, dia e noite. Antes, o sujeito do sonho seria o próprio sonho, pequena grande parte de verdade que se oculta nas ilusões de nós mesmos, relação essa que

de 1981, e também no primeiro capítulo: Sonhar com os próprios prazeres, de História da sexualidade III - o cuidado de si (1985). Embora tal ponte entre ambos momentos seja instigantíssima para pensarmos uma analítica onírica no pensamento de Michel Foucault, devido aos propósitos temáticos desse artigo, bem como o limite de espaço para a sua exposição, não os enfocarei nessa oportunidade.

11 FREITAS, Os perigos de uma ontologia política ainda sem cabimento ou o legado ético-espiritual de Michel Foucault 2016, 23.

12 PERENCINI, Educação, filosofia e magia: uma anarqueologia do cuidado de si entre o daimon e os sonhos.

${ }^{13}$ FOUCAULT, Subjetividade e verdade, 46-47.

${ }^{14}$ FOUCAULT, Subjetividade e verdade, 46. 
causa certa fissura para a constituição do saber com status e pretensão científica. É por isso que a constituição da mathesis pela qual o sujeito cartesiano - único supostamente capaz de pensar a verdade em termos racionais e científicos - foi ancorado implica extirpar o desconhecido do sonho que dorme na subjetividade. A essa configuração de sujeito, "foi preciso garantir-lhe que efetivamente não está sonhando quando tem acesso à verdade, ou, em todo caso, que o acesso que tem a verdade não pode ser ameaçado nem comprometido pela eventualidade do sonho"15.

Os sonhos funcionam como um tipo de "saber proibido" frequentemente vinculado aos desvarios da razão pela loucura, o que permite criar uma aliança de pensamento entre filosofia e magia. Não será muito lembrar que Foucault caracteriza a cultura pela qual se ambienta o pensamento mágico como uma "cultura ocupada por Deus, pelo mundo, pela semelhança das coisas, pelas leis do espaço, certamente também pelo corpo, pelas paixões, pela imaginação. Mas o próprio homem está ausente por completo"16. Esse entrelaçamento permite pensar a contemporaneidade como uma potência filosófica que não vem do lugar do sujeito e da luminosidade, mas sim da história da subjetividade, que possibilitaria reconciliar uma arte de viver que não silenciasse a metafísica da alma, máxima foucaultiana encontrada no mundo arcaico que permanece como desafio para o tempo presente.

A tarefa arqueológica descarta de antemão a existência de qualquer universal e procura identificar as rupturas e descontinuidades inerentes ao solo sobre o qual uma verdade foi demarcada. Para essa prática de pesquisa não existe passado sancionado ou ultrapassado e por isso uma leitura de penumbra entre os limiares de epistemologização e campos de saberes se faz necessária. Tal aporte não toma a nossa atualidade científica como evolução e progresso, se comparada às formas de nos relacionarmos com as práticas e saberes do passado. Particularmente, a leitura arqueológica imprimida por Foucault permite escapar à interpretação tradicional da história das ideias, que reduz a magia às formas de conhecimento supersticiosas e identifica o século XVII como aquele em que tais crenças desaparecem a fim de possibilitar a entrada da natureza científica na relação com o saber e o mundo. Foucault, ao contrário, oferece-nos uma perspectiva bem diferente dessa porque não considera a magia como um mero efeito residual da consciência europeia feudal, mas identifica nesse pensamento uma forma de conhecimento que não pode ser confinado à representação e à significação, resgatando linhas de fuga epistemológicas que foram abandonadas com o iluminismo. Ora, a magia é um modelo de pensamento silenciado desde o século XVII justamente porque escapa aos termos universais da razão e da verdade.

Mais precisamente, a leitura arqueológica impressa em As palavras e as coisas evidencia como a arquitetura científica pela qual foi ancorado todo um discurso de evolução do pensamento ocidental desde os séculos XVII implicou no apagamento da forma mágica como maneira de conhecer o mundo habitado. A magia à época era uma forma de aprendizado movida pelo paradigma da semelhança ${ }^{17}$, uma relação estabelecida com o conhecimento que inclui os saberes sujeitados das pessoas em suas formas locais de pensar e sentir, como práticas com racionalidades próprias. Para essa forma de conhecer, o mundo seria "coberto de signos que é preciso decifrar, e estes signos, que revelam semelhanças e afinidades, não passam, eles próprios, de formas de similitudes"18 que se cruzam infinitamente, criando possibilidades novas de conhecimento. Não se trata de uma forma estritamente científica com

\footnotetext{
15 FOUCAULT, Subjetividade e verdade, 46.

16 FOUCAULT, Ditos e escritos VII, 152.

17 A leitura arqueológica mostra que esse corpus de semelhança era meticulosamente organizado até o século XVI, ainda que para os nossos olhos contemporâneos toda essa rede de saber pareça sofrivelmente confusa. Como consta em As palavras e as coisas (FOUCAULT, 2002a) há ao menos cinco noções fundamentais que conduzem o pensamento mágico na era da semelhança: convenientia, emulatio, analogia, simpatia e assinatura, como procurei pormenorizar em Perencini (2019).

18 FOUCAULT, As palavras e as coisas, 44.
} 
a verdade, que confina a nossa maneira de conhecer ao dualismo e binarismo (ou/ou), mas aposta nas analogias (e/e) e na multiplicidade dos seres.

Foucault entende que será preciso nos determos melhor no paradigma mágico, modelo presente desde antes dos gregos até o século XVI, pois ele opera em uma forma de se relacionar com o conhecimento que ultrapassa os limites da representação, que confina a linguagem à crítica e ao distanciamento entre sujeitos e objetos. 0 paradigma que rege o jogo das semelhanças acolhe, ao mesmo tempo e no mesmo plano, magia e erudição. A forma de conhecimento entendida dessa maneira não silencia práticas como a astrologia, a fisiognomia e a quiromancia, pois elas ensinam a "decifrar o segredo do 'homem interno' nos signos que os astros imprimiram sobre o rosto e sobre os membros dos homens ou nas linhas de suas mãos"19. As práticas mágicas nesse sentido são formas de ler o cosmo, que se encontram muito para além dos textos e das teorias e os saberes divinatórios não concorriam com as formas científicas de conhecimento, mas se incorporavam a elas, pois caberia aos atores da magia a tarefa de ler aquilo que não fora escrito nos textos.

Procurei mostrar em Perencini ${ }^{20}$ a importância da magia para a arqueologia foucaultiana. Como aponta Agamben ${ }^{21}$, antes de recorrer à arqueologia filosófica de Kant, como habitualmente se lê, Foucault rouba a noção de a priori histórico da noção de mana, ${ }^{22}$ como consta no pensamento de Marcel Mauss ([1902-03] 2003) em seu Esboço de uma teoria geral da magia. 0 verbo roubar é usado propositalmente, já que Foucault nunca cita Mauss, embora seu amigo íntimo Paul Veyne ${ }^{23}$ enuncie que o pensador francês lia apaixonadamente esse autor em seus anos de juventude.

Recorrer a mana é importante para tal artigo porque Mauss aponta que, embora a sua dimensão mística tenha sido plenamente esvaziada no presente, é possível encontrar esse conceito sob a forma de phýsis (natureza) e dýnamis (potência) na Grécia arcaica, umbral de nossa tradição filosófica ocidental:

Ali a encontramos sob o aspecto da phýsis, na qual se detêm, em última análise, os alquimistas, e também da dýnamis, instância última da astrologia, da física e da magia. A dýnamis é a ação da phýsis, e esta é o ato da dýnamis. E pode-se definir a phýsis como uma espécie de alma material, não individual, transmissível, uma espécie de inteligência inconsciente das coisas. Em suma, ela é também muito próxima do mana ${ }^{24}$.

A interface entre o pensamento de Foucault e Mauss nos conduz à catábases, experiências de viagens místicas e visionárias de almas que perambulavam aos infernos na

\footnotetext{
${ }^{19}$ AGAMBEN, Signatura Rerum - sobre el método, 49.

20 PERENCINI, Arqueologia e Magia.

${ }^{21}$ AGAMBEN, Signatura Rerum - sobre el método, 130.

220 mana não é universal, mas se trata de uma ressonância comum a certo número de sociedades. Independente da nomenclatura (mana, orenda, kramat, etc.), Maus identifica que uma noção comum encontra-se como base para a execução dos ritos mágicos. Mana é potência e não implica a sua passagem para o ato. Dessa maneira, não se pode querer examinar mana com o olhar crítico ocidental habitual, uma vez que se trata aqui de uma categoria inconsciente do intelecto e funciona como um meio que torna possível os atos de pensamento e criação, transcendendo ao próprio humano. Mana sugere que os modelos epistemológicos escapam às leis objetivas da dedução e da indução, que há neles uma forma de imaginação ativa nem sempre explicável e por isso ela não obedece à lógica da homogeneidade nem da consciência. Mauss ainda afirma que na Grécia, berço de nossa tradição cultural, o poder mágico de sua noção foi esvaziada de seu conteúdo místico e convertida à mitologia, "uma demonologia completa, conseguiram reduzir de tal modo a termos míticos tudo o que havia de impreciso e de obscuro em suas representações mágicas, que substituíram, ao menos aparentemente, o poder mágico, sempre que era preciso explicá-lo, pelo demônio, pelos demônios ou por entidades metafísicas" (Sociologia $e$ Antropologia, 150).

23 VEYNE, Foucault: seu pensamento, sua pessoa, 46.

24 MAUSS, Sociologia e Antropologia, 151.
} 
antiguidade grega arcaica, uma noção proveniente do xamanismo, quando a filosofia não se pressupunha propriamente crítica.

0 tipo de espiritualidade como força arcaica operante que podemos reatualizar junto aos últimos cursos de Foucault é a penumbra pela qual conviviam filosofia e xamanismo ${ }^{25}$, amálgama entre as sabedorias do Ocidente e do Oriente, nessa época "pré-histórica" em que as esferas sagradas e profanas ainda não se distinguiam - ou não se tinham confinado pela forma institucionalizada e jurídica, como já é possível presenciar tomando a emergência da vontade de saber em Édipo Rei. 0 xamanismo pode ser considerado como um fenômeno social oriundo das civilizações da caça em que o xamã se liga a um ser da floresta, parte humano, parte animal, parte vegetal; um mago que por dom e/ou aprendizado iniciático transita entre diferentes estados de consciência e mundos ${ }^{26}$.

Louis Gernet, pesquisador de grande inspiração para Foucault, orienta-nos a tomar nota de que aquilo que conhecemos por filósofo é "o sucessor de um tipo inspirado que apresentava os traços do vidente extático - e que lhe deixava transluzir aspirações de profeta e curandeiro" (27tradução nossa) à maneira de um xamã. 0 mesmo é sugerido por Dodds, que identifica também a cesura entre a filosofia e o xamanismo, em virtude da desintegração das funções múltiplas que ocupava o xamã:

O xamã que combina as funções ainda indistintas do mago e do naturalista, do poeta e do filósofo, pregador, curador e conselheiro. Depois dele estas funções sofreram uma desintegração; dali em diante os filósofos não mais seriam nem poetas nem $\operatorname{magos}^{28}$.

0 poder encantatório da música e da poesia move a catarse xamânica. Uma vez que a música é a "língua dos espíritos", a prática de evocar ou conjurar forças astrais ocorria justamente pela canção como a força originária do transe, espécie de êxtase como força de elevação para fora de $\mathrm{si}^{29}$. A alma do xamã pode abandonar o corpo e viajar para lugares distantes, mais frequentemente para o mundo dos espíritos, e o corpo pode ser visto em lugares simultâneos, contando com um número múltiplo de vidas, onde "a experiência de vidas passadas não é uma fonte de culpa, mas uma intensificação do poder"30 conferido por suas práticas espirituais que a ele retornam em forma de dons.

Ele tem o poder da ubiquidade. A partir destas experiências, narradas por ele através de canções extemporâneas, ele vai extraindo a habilidade para a adivinhação, para a poesia religiosa e para a medicina mágica que acaba por torná-lo socialmente importante. Ele se torna o repositório da sabedoria sobrenatural ${ }^{31}$.

De maneira bem diferente ao discurso do racionalismo e da transcendência que se emoldurou pelo helenismo grego, a noção arcaica e xamânica de alma (psykhé) permite-nos observar com maior clareza a imanência entre corpo e alma. Essa noção pode ser definida por "algo de móvel. A alma, o sopro, é algo que pode ser agitado, atingível pelo exterior. E é

\footnotetext{
${ }^{25}$ Foucault vai se referir especificamente ao xamanismo na aula de 13 de janeiro de 1982, em A hermenêutica do sujeito, a partir do livro de Henri Joly, intitulado Renversement platonicien Lógos-Epistéme-Pólis. Há nesse livro “cerca de uma dúzia de páginas sobre esta preexistência, ali atribuída à 'estrutura xamanística' - palavra discutível, mas isso é irrelevante. Ele insiste na preexistência de algumas dessas técnicas na cultura grega arcaica (técnicas de respiração, técnica do corpo, etc.). Pode ser tomado como referência. Em todo caso, é um texto que me trouxe algumas ideias, e fui desatento em não citá-lo antes" (FOUCAULT, A hermenêutica do sujeito, 62).

${ }^{26}$ ELIADE, $O$ xamanismo e as técnicas arcaicas do êxtase.

27 GERNET, Antropología de la Grecia Antigua, 372.

${ }^{28}$ DODDS, Os gregos e o irracional, 150.

${ }^{29}$ DODDS, Os gregos e o irracional, 176 - 177.

30 DODDS, Os gregos e o irracional, 154.

${ }^{31}$ DODDS, Os gregos e o irracional, 154.
} 
preciso evitar que a alma, esse sopro, esse pneûma se disperse"32. Doods nos chama a atenção de que na Grécia arcaica essa "palavra não possuía nenhum sabor de puritanismo, e nem sequer gozava de qualquer status metafísico. A 'alma' não era nenhuma prisioneira do corpo, mas sim a vida ou o espírito do corpo, sentindo-se perfeitamente à vontade ali"33. A propósito, ele nos lembra que antes de Platão, tal noção raramente ou quase nunca é citada como sede da razão, mas aproxima-se mais a noção de thumos, sopro vital localizado na altura do peito (coração) ou do ventre, intuição relacionada à emoção, como uma voz demoníaca, interna do homem a lhe transmitir mensagens que visam ao seu despertar à maneira como faziam os yoguis orientais ${ }^{34}$. Reside aí todo um capítulo instigante entre Sócrates e seu daímon, que detalhei em outra oportunidade ${ }^{35}$.

A questão é que o curso da história ocidental parece ter silenciado certa potência de cura e poderes psíquicos como a telepatia e intuição em que o xamanismo se assentava em sua emergência na filosofia ocidental. Dodds sugere que o corte entre filosofia e xamanismo parece tomar forma com a filosofia platônica. Ele é claro em afirmar que "Platão efetivamente fecundou a tradição racionalista grega com ideias mágico-religiosas, cujas origens remotas pertencem à cultura xamanística do norte"36. Com isso Dodds quer dizer, por um lado, que o racionalismo platônico "é precipitado por ideias que pertencem em um dado momento à magia; e veremos mais tarde como tais 'encantações' vieram servir para fins racionais"37. Tais 'encantações' são os recursos aos mitos funcionando como recurso argumentativo no filósofo grego. Já, por outro lado, "para as intuições do vidente e do poeta, Platão consistentemente recusava o rótulo de conhecimento, não por achá-las necessariamente desprovidas de fundamento, mas porque não era possível apresentar suas bases"38.

Ainda que os elementos de ambas as tradições permaneçam em penumbra no filósofo grego, será preciso reconhecer que a sua filosofia já promove uma completa interpretação do velho padrão da cultura xamanística.

A reencarnação sobrevive sem alterações. 0 transe xamanístico, com a correspondente separação do 'eu' oculto, torna-se uma prática mental de reclusão e meditação que purifica a alma racional - uma prática para a qual Platão reivindica a autoridade do logos tradicional. 0 conhecimento oculto que o xamã adquire durante o transe torna-se uma visão da verdade metafísica; a 'recordação' de vidas passadas torna-se reminiscência de Formas incorpóreas, constituindo a base de uma nova epistemologia. No nível mítico, o 'longo sono' e a 'viagem ao submundo' fornecem um modelo direto para as experiências de $\mathrm{Er}^{39}$.

Afora isso, Platão parece concluir não haver lugar na gestão do Estado para os sonhos e para a loucura. "A verdade platônica é produto do rigoroso pensamento da vigília, e não das alucinações oníricas induzidas pelo sono, pela enfermidade e pela intoxicação"40. Dessa maneira, "era uma tarefa de julgamento racional distinguir entre o verdadeiro vidente e o charlatão. Do mesmo modo, os produtos da intuição poética deviam estar sujeitos à censura moral e racional de um legislador treinado" 41 .

\footnotetext{
32 FOUCAULT, A hermenêutica do sujeito, 44

33 DODDS, Os gregos e o irracional, 143.

${ }^{34}$ ELIADE, Yoga: imortalidade e liberdade, 13.

35 PERENCINI, Educação, filosofia e magia: uma anarqueologia do cuidado de si entre o daimon e os sonhos.

36 DODDS, Os gregos e o irracional, 211.

37 DODDS, Os gregos e o irracional, 214.

38 DODDS, Os gregos e o irracional, 218.

${ }^{39}$ DODDS, Os gregos e o irracional, 212.

40 RIBEIRO, $O$ oráculo da noite, 73.

41 DODDS, Os gregos e o irracional, 218.
} 
0 gesto de exorcizar todas as formas equívocas do outro, limitando para isso a loucura e o sonho como formas de acesso à verdade, parece confundir-se com o curso da história cronológica do Ocidente e, com ela, da própria filosofia ocidental. Para além do argumento comum de que o demônio se instaura na mente e na intimidade do corpo, a novidade que a pesquisa arqueogenealógica nos apresenta é a vinculação da experiência demoníaca aos sonhos como formas de acesso à verdade que pertence ao erro e à ilusão, dirimindo a possibilidade de pensar a política em termos de imaginação, que nos convocaria a sonhar com outras formas de vida e de mundos possíveis. "Não é ele [o demônio] que, quando a vontade do homem está adormecida, comanda os sonhos? 0 demônio é o mestre dos sonhos, a grande potência enganadora" 42 . "A ação demoníaca não acontecerá no próprio mundo, mas entre o mundo e o homem ao longo da superfície da 'fantasia' e dos sentidos, ali onde a natureza se transforma em imagem" 43 . Tudo o que está nos limites da alma, da fantasia e do sonho tornase por direito de vizinhança domínio privilegiado do demônio, já que ele não se manifesta apenas na noite do inconsciente, mas sataniza também a subjetividade afeita à imaginação na luz do dia. Sonhar com outros mundos torna-se, portanto, um artifício do vândalo, do infame e da bruxa.

A exclusão é a forma de julgamento por excelência ao que a consciência ocidental, principalmente desde a modernidade, experimenta como estrangeiro, já que o outro se encaixa na categoria de "não explicável" e da "desrazão". Por exemplo, é pela força da imaginação e fantasia que os espíritos das bruxas são aliciados pelo diabo. "Não se dá folga ao demoníaco: ao contrário, ele é reaproximado e infinitamente fixado à articulação da alma e do corpo, ali onde nasce a imaginação"44. A maneira de conjurar o demônio apossado da alma e do corpo é silenciando a força da imaginação e do sonho. Elas devem ser silenciadas porque "o demoníaco comanda todos os acessos à verdade. Seu poder se identifica com a própria possibilidade do erro" 45 .

Não é novidade que desde o século XIII a bruxaria e a magia popular foram definidas como heresias pelas mais altas autoridades da Igreja. Já Foucault possibilita-nos a percepção de que "o desenvolvimento do saber médico no século XVI não está ligado à substituição do sobrenatural pelo patológico, mas ao aparecimento dos poderes transgressivos do corpo e da imaginação"46. Teremos a prova disso no século XVII, quando se farão a todos que imaginam, como os visionários e os insensatos, sofrerem no internato o mesmo tipo de exclusão, sob a justificativa de delírio e engano. A igreja tornou-se "a mais obstinada em convocar o testemunho médico contra os fenômenos extáticos" 47 que enchiam a cabeça dos pobres com predições imaginárias. Na contramão disso, um espírito instruído e adestrado a ser reconduzido ao conhecimento de Deus virá ao preço de não acreditarmos nos desvarios da magia, "que abusa das coisas sagradas e submete a religião aos caprichos da imaginação e aos desregramentos das paixões" 48 .

Pensando com Foucault ${ }^{49}$, podemos inferir que a demonologia foi ancorada por um campo de saberes, poderes e instituições que tangenciam desde o capitalismo, passando pela Inquisição cristã, até o discurso filosófico. Filosofia primada pelos teóricos políticos do Estado, como o modelo hobbesiano, que nega a possibilidade de uma razão livre do corpo, delegando suas funções de mando às artes de governo do Estado, mas também aos "pais" do racionalismo científico moderno, a começar pelo modelo cartesiano, que separa a alma do

\footnotetext{
42 FOUCAULT, Ditos e escritos VII, 274.

${ }^{43}$ FOUCAULT, Ditos e escritos VII, 274.

${ }^{44}$ FOUCAULT, Ditos e escritos VII, 277.

${ }^{45}$ FOUCAULT, Ditos e escritos VII, 277.

${ }^{46}$ FOUCAULT, Ditos e escritos VII, 278.

47 FOUCAULT, Ditos e escritos VII, 297.

48 FOUCAULT, Ditos e escritos VII, 298.

${ }^{49}$ FOUCAULT, A arqueologia do saber.
} 
corpo e relega esse à condição de máquina e com isso fecunda o desenvolvimento dos mecanismos de autodisciplina e autocontrole no indivíduo.

À contrapelo do que nos faz crer a demonologia, elegendo a possibilidade de sonhar com outras formas do real um artifício do tinhoso, suponho que a magia encontrada nos saberes e práticas populares não deixou de existir entre nós, ainda que hoje habite nosso imaginário como mera forma de crendice, reduzida à simpatias. Não de modo fortuito, o inferno com suas estranhezas particulares vem perturbar as estruturas científicas e filosóficas de conhecimento que caracterizaram a nossa modernidade. Proponho como sequência deste artigo uma maior compreensão sobre a questão, de tal maneira que viajar aos infernos busca tornar visível a ambiguidade presente na emergência das ciências humanas e, mais precisamente, daquilo que teve de se esconder à soleira da porta para que determinada concepção ilustrada de ciência humana fosse emoldurada em nossas estruturas de saber.

\section{Humanismo, sono antropológico e pensamento visionário}

Foucault entende que um dos maiores trabalhos políticos de nosso tempo presente é nos libertarmos definitivamente do humanismo e, mais particularmente, daquilo que ele veio chamar de sono antropológico, pelo qual a filosofia e as ciências humanas se encontram adormecidas na contemporaneidade.

Eu diria simplesmente que houve uma espécie de sono antropológico no qual a filosofia e as ciências do homem se fascinaram, de algum modo, e se adormeceram umas às outras, e que é preciso acordar desse sono antropológico, como outrora acordou-se do sono dogmático ${ }^{50}$.

Foucault refere-se aqui a sono antropológico com uma dupla crítica às antropologias filosóficas contemporâneas e à própria instauração dessa temática antropológica no pensamento ocidental, ancorada na ideia do homem enquanto sujeito e objeto originário do saber, modernidade da qual ainda não saímos. Para essa compreensão humanista e antropológica, o ser humano distingue-se dos demais seres por seu atributo racional, que lhe permite ser livre e feliz. Ele aponta que, de algum modo, a filosofia kantiana e com ela o pensamento posterior restringe o filosofar a uma problemática fundante: o que é o homem?

0 interesse do pensador francês é mostrar, por outro lado, e como bem sabemos, "que o homem não passa de uma invenção recente, uma figura que não tem dois séculos, uma simples dobra do nosso saber, e que desaparecerá desde que este houver encontrado uma forma nova"51. Ao deflagrar a morte do homem - assassino de Deus, como já havia antecipado Nietzsche - Foucault entende a necessidade de suspender modelos éticos justificados em teorias da natureza humana circunscritas na razão como valor universal, algo que bem aclara em uma entrevista marginal concedida por ocasião da Revolução Iraniana em 1978:

Aquilo que eu criticava precisamente na noção de homem, e no humanismo dos anos 1950, 1960, era a utilização de um universal entendido como universal-noção. Haveria uma natureza humana, haveria necessidades humanas, haveria uma essência humana, etc. E é em nome desse universal do homem que faríamos revoluções, aboliríamos a exploração, nacionalizaríamos indústrias, deveríamos nos filiar ao Partido Comunista, etc. Esse universal que permite muitas coisas e que, ao mesmo tempo, supunha, de maneira

50 FOUCAULT, Ditos e escritos I, 293.

51 FOUCAULT, As palavras e as coisas, XXI. 
ligeiramente ingênua, uma espécie de permanência trans-histórica, subhistórica ou meta-histórica do homem ${ }^{52}$.

A convocatória para que a contemporaneidade desperte do universalismo que rege esse estado de dormência requer encontrar uma ontologia apartada do campo antropológico, que possa se constituir como pensamento radical do ser, colocando fora do circuito, "além do psicologismo e do historicismo, todas as formas concretas do preconceito antropológico, [para que] se tente reintegrar os limites do pensamento e reatar assim com o projeto de uma crítica geral da razão" 53 .

Pensando com Foucault, encontro uma crítica geral da razão pelo qual se instaurou o pensamento antropológico na enunciação de uma ontologia onírica, calcada no sonho enquanto experiência visionária da psique (alma), algo que nunca chegou a desenvolver concretamente, embora nos sugira pistas para o fazer. Para que um pensamento do homem enquanto ente racional fosse ancorado, o sonho, a imaginação e a loucura tiveram de ser silenciadas e tem sido justamente essa dobra que me interesso em resgatar quando me aproximo da magia como forma de conhecimento no mundo.

Posto isso, se "a antropologia constitui talvez a disposição fundamental que comandou e conduziu o pensamento filosófico desde Kant até nós" ${ }^{\prime 4}$, será preciso escavar pela emergência do homem junto ao pensamento do filósofo ilustrado, peça-chave para compreendermos por que a filosofia ao se despertar do sono dogmático volta-se para o sono antropológico. Textos protoarqueológicos do jovem Foucault dão-nos pistas interessantíssimas sobre tal projeto crítico geral da razão antropológica.

No contexto protoarqueológico, Foucault atenta-se ao professor Kant em seu período pré-crítico, também pouco interessante para a exegese dedicada a esse autor. Foucault aborda a temática antropológica em sua Tese complementar, conhecida por Gênese e Estrutura da Antropologia de Kant, pesquisa desenvolvida entre 1959 e 1960 em Hamburgo, onde estavam conservados os escritos do filósofo alemão ${ }^{55}$. Será já no Prefácio da Antropologia de um ponto de vista pragmático - curso ministrado em 1772/1773 e só publicado em 1797, posteriormente à morte de Kant - que ele menciona seu grande propósito com esse trabalho: "investigar o que o homem, como ser livre, faz, pode ou deve fazer de si mesmo" 56 , temática abordada pelo jovem Foucault já entre a década de 1950 e 1960 e que, curiosamente, se verterá em seus últimos cursos na forma de uma ontologia do presente, pensada paralelamente ao cuidado de si.

Teço, para o presente dossiê, um movimento similar e concomitantemente diferente do que fez o jovem Foucault ao resgatar o professor Kant: similar, pois interesso-me por temáticas próximas as tratadas por Kant no período em que Foucault o busca, como é o caso da experiência onírica ou da cura; diferente, pois, em lugar de me deter à problemática antropológica, como fez o pensador francês, procuro enfocar aquilo de que teve de se esquivar para que o sono antropológico fosse ancorado em nossas estruturas contemporâneas de pensamento, qual seja, suas considerações sobre o pensamento onírico e visionário.

Tarefa que implica no resgate da dissertação Sonhos de um visionário explicados por sonho da metafísica (2005 [1766]), considerado durante muito tempo como um trabalho irrelevante dentro do corpus kantiano ${ }^{57}$, texto que Foucault conheceu, ainda que não se

\footnotetext{
52 FOUCAULT, 0 enigma da revolta, 85.

53 FOUCAULT, As palavras e as coisas, 472.

${ }^{54}$ FOUCAULT, As palavras e as coisas, 473.

55 Como nos mostra Terra (1997, p. 75): "A antropologia kantiana estaria articulada a três conjuntos de pesquisas: em primeiro lugar, às obras pré-críticas, como as Observações sobre o sentimento do belo e do sublime (1764), o Ensaio sobre as doenças do espírito (1764) e o Ensaio sobre as raças (1775), nas quais se encontram temas da Antropologia, mas com grandes diferenças na ordenação dos materiais".

56 FONSECA, MUCHAIL, Gênese e estrutura da antropologia de Kant, 12.

${ }^{57}$ CUNHA, Sonhos de um Visionário e suas contribuições para a ética de Kant, 105.
} 
detenha nele ${ }^{58}$. A temática central dos Sonhos é o interesse de Kant pelo mundo espiritual e, em particular, pela experiência onírico-visionária de Emanuel Swedenborg, vidente sueco, teósofo e precursor do espiritismo. O posicionamento do filósofo alemão nesse texto é paradoxal: ele tanto zomba do esoterismo, relegado por ele à pura metafísica, quanto se impressiona com um certo pensamento visionário que desafiaria as leis a priori de tempo e espaço em que a filosofia crítica viria a se ancorar posteriormente. Entender por que a experiência visionária caracteriza-se como uma pedra no sapato para a filosofia crítica é tarefa fundamental para esse dossiê.

Antes de me adentrar na argumentação dos Sonhos, gostaria de ressaltar uma consideração geral sobre a sua forma de escrita. Trata-se de um texto visual, povoado de imagens quase caricaturais, onde Kant destila uma série de ironias, sátiras e metáforas quando se refere ao pensamento visionário, ao ponto de um leitor acostumado com a aspereza dos escritos críticos mal reconhecer sua autoria nesse texto pregresso. A questão do estilo é significativa para a análise que empreendo, porque Kant parece conferir à experiência visionária algo de pouca importância, "um assunto ingrato a que o pedido e a insistência de amigos curiosos ociosos me submeteram" 59 .

Ao contrário de tal suposição, a leitura de Cunha ${ }^{60}$ e Girotti ${ }^{61}$ mostram que o debruçamento sobre o pensamento visionário nos Sonhos foi fundamental para que a Crítica fosse ancorada enquanto a sua dobra, o que faz do esoterismo uma prática filosófica à sombra do iluminismo e, posteriormente, também das ciências humanas. Escondido sob o diletantismo irônico de Kant, encontram-se nos Sonhos intuições sobre a experiência ética humana e onde o filósofo tem de reconhecer que não existe uma prova irrefutável de que os seres orgânicos sejam os únicos portadores da vida, abrindo campo para o mundo espiritual. "Temos, a partir da hipótese do mundo espiritual, as primeiras indicações do conceito que, mais tarde, seria chamado por Kant de liberdade em sentido positivo e negativo, bem como a emergência da ideia geral de formalismo e do imperativo categórico"62, já que em seus escritos posteriores, nomeadamente críticos, Kant visava a encontrar um fundamento racional que pudesse garantir o agir moral nesse mundo mesmo.

Trata-se os Sonhos de uma dissertação dividida em duas partes. A primeira delas compreende uma reflexão sobre o mundo espiritual, universo afirmado por Kant sem qualquer esperança de ser demonstrado mediante fundamentos racionais pela experiência e, portanto, sem a possibilidade de ser refutado. Como ele mesmo afirma: "confesso estar fortemente inclinado a afirmar a existência de naturezas imateriais e incluir minha própria alma na classe desses seres. Mas, então, quão misteriosa não se torna a comunidade entre um espírito e um corpo"63. Embora Kant confesse tal suposição, seu argumento é tecido na direção de criticar o pensamento esotérico, aquele que lida com a "existência de seres imateriais, cujas leis causais particulares são chamadas de pneumatológicas e, na medida em que os seres corporais são causas intermediárias de seus efeitos no mundo material, orgânicas"64. A filosofia nomeada por Kant de pneumatológica entende a vida como atividade intermediária entre o mundo material e o mundo imaterial, sendo este possível de ser acessado através de exercícios espirituais capazes de nos abrir à clara intuição (clarividência).

\footnotetext{
58 Ele cita explicitamente esse texto na aula de 21 de janeiro de 1981, curso Subjetividade e verdade, indicando que a partir dele Kant se coloca a questão: se a verdade da verdade é realmente verdadeira. Na ocasião, ele faz uma menção direta ao interesse de Kant pela teosofia de Swedenborg. Conferir Foucault (2016, p. 46-65).

59 KANT, Escritos pré-críticos, 209.

${ }^{60}$ CUNHA, Sonhos de um Visionário e suas contribuições para a ética de Kant.

${ }^{61}$ GIROTTI, Kant e os 'Sonhos de um Visionário': um escrito pré-crítico de cunho crítico?.

${ }^{62}$ CUNHA, Sonhos de um Visionário e suas contribuições para a ética de Kant, 93.

63 KANT, Escritos pré-críticos, 156.

${ }^{64}$ KANT, Escritos pré-críticos, 159.
} 
As leis pneumatológicas unem a singularidade da alma ao comum do mundo, em um processo integrado que compreende o passado, o presente e o futuro do espírito, indicando essa vida como um ato sequenciado de existência pregressa que, inevitavelmente, será também a causa de outra vida ainda por vir, após a morte. Kant resume bem o ciclo da existência para o pensamento esotérico no fragmento a seguir:

Quando então finalmente estivesse abolida na morte a comunidade da alma com o mundo corporal, a vida no outro mundo seria apenas uma continuação natural daquela conexão em que ela já se encontrava com ele nesta vida, e todas as consequências da moralidade ali exercidas seriam encontradas lá nos efeitos como todo o mundo dos espíritos já causou ali antes, de acordo com leis pneumatológicas. 0 presente e o futuro seriam, portanto, como que uma só peça e formariam um todo contínuo, mesmo segundo a ordem da natureza 65 .

O posicionamento kantiano é claramente assumido contra um tipo específico de esoterismo, a cabala, como sugere o terceiro capítulo da primeira parte do texto: "Anticabala: um fragmento da filosofia comum, para superar a comunidade com o mundo dos espíritos"66, que o filósofo alemão nomeia ironicamente por uma filosofia como "conto do país das fadas da metafísica"67, uma vez que para os cabalistas seria possível estabelecer comunicações com o "mundo dos mortos".

Sim, isto parece ser também em geral a principal causa da credibilidade das histórias sobre espíritos, tão difundidas e mesmo as primeiras ilusões acerca de supostas aparições de pessoas defuntas nasceram presumivelmente da esperança lisonjeira de que se continue de algum modo depois da morte, tendo então a ilusão enganado os sentidos em sombras noturnas e criado a partir de figuras ambíguas fantasmas adequados às opinião precedente... ${ }^{68}$.

Em suma, para Kant, "a pneumatologia dos homens pode ser chamada uma doutrina de sua necessária ignorância em vista de uma suposta espécie de seres e como tal ser facilmente apropriada à tarefa" 69 de se comunicar com outras formas de vida e de mundos externos ao nosso.

O sonho é um elemento irradiador de discórdia entre Kant e o esoterismo. Por um lado, a cabala ancora-se na ideia de que os sonhos são nutridos por uma força mágica que cruza o visível e o invisível, conferindo-lhes o dom de emitir sinais e premonições sobre acontecimentos não apenas dessa vida, mas também do mundo espiritual para além daquilo que podemos acessar pela noção de tempo e espaço contritos na vigília. Dessa maneira, para o pensamento cabalístico, os sonhos cruzariam não apenas o tempo (presente, passado e futuro), mas também o espaço (outras dimensões e mundos possíveis).

Já Kant visa deslegitimar a cabala em sua compreensão sobre o potencial dos sonhos e para isso recorre a Aristóteles: "Aristóteles diz em algum lugar: quando estamos acordados, temos um mundo comum, mas quando sonhamos cada qual tem seu próprio"70 (grifo do autor), dando a entender que os sonhos não passam de uma questão privada de cada sujeito, distanciando-se do universo comum e político que corresponde à luz do dia na vigília. Em tom de zombaria, o filósofo alemão dedica-se a mostrar o caráter delirante e fantasioso dos sonhos, "representações de que aquele que dorme se lembra ao despertar [...] quimeras

\footnotetext{
${ }^{65}$ KANT, Escritos pré-críticos, 169.

${ }^{66}$ KANT, Escritos pré-críticos, 176.

${ }^{67}$ KANT, Escritos pré-críticos, 194.

68 KANT, Escritos pré-críticos, 184.

${ }^{69}$ KANT, Escritos pré-críticos, 189.

${ }^{70}$ KANT, Escritos pré-críticos, 176.
} 
selvagens e absurdas, como elas tem de ser necessariamente, uma vez que nelas foram misturadas ideias da fantasia e da sensação externa"71. 0 universo onírico nos termos do esoterismo desdobra-se nos estados visionários e no dom da vidência, um conhecimento intuitivo do mundo que, para Kant, "só pode ser obtido aqui na medida em que se perde um pouco daquele entendimento de que se tem necessidade para o mundo presente"72.

0 argumento central que Kant ${ }^{73}$ utiliza para invalidar tais narrativas mágicas é justamente recorrer ao corpo mecânico de Descartes para apontar que tais visionários aqueles que "põem fora de si a ilusão de sua imaginação"74 - não passariam de homens doentes, acometidos por uma disfunção cerebral.

Espécie de distúrbio do ânimo que se chama parestesia [Wahnsinn] e, em graus menores, a alienação [Verrückung]. 0 próprio dessa doença consiste em que o homem confuso põe fora de si simples objetos de sua imaginação e os considera como coisas efetivamente presentes diante dele ${ }^{75}$.

A consequência dessa doença para o cérebro do enfermo faz com que ele confunda a vigília com o sono e tome a imagem onírica, "obra simplesmente da imaginação"76, como um objeto do real. Por isso, em tom sarcástico, Kant reitera que será preciso "paciência com a contradição de suas visões, até que estes senhores tenham acabado de acordar"77 de seu estado embriagado da imaginação.

Por isso, de modo algum levo a mal se o leitor, em vez de tratar os visionários como meio-cidadãos do outro mundo, despachá-los simplesmente como candidatos ao hospício, dispensando-se assim de qualquer investigação ulterior [...] e, como se achava outrora necessário queimar alguns deles, agora será suficiente apenas purgá-los (grifo do autor) ${ }^{78}$.

0 diletantismo retórico de Kant, ao comparar os visionários às bruxas outrora queimadas, repete o pensamento demonólogo, que faz do diferente o limite estranho e monstruoso do próprio pensamento racional, relegando o sonho à mera ilusão, mas passível de correção pela análise crítica.

Posicionamento esse que nos faz pensar: Por que os saberes visionários merecem tanta atenção aos olhos do "pai" do iluminismo ocidental? Ou, mais precisamente, por que a experiência visionária perturba a filosofia crítica? Incomoda a Kant que pessoas racionais aceitem práticas como a "simpatia, a vara de achar água, as premonições, o efeito da imaginação de mulheres grávidas, as influências das fases lunares sobre animais e plantas, etc"79, da mesma maneira que o pensamento visionário o intriga e por isso merece a atenção enquanto campo problemática a ser tornado visível nesse artigo. 0 que está em jogo aqui são dois projetos distintos de filosofia e pedagogia, que fará com que Kant entre em disputa com o pensamento místico e visionário até o final de sua vida ${ }^{80}$.

\footnotetext{
${ }^{71}$ KANT, Escritos pré-críticos, 171.

72 KANT, Escritos pré-críticos, 175.

${ }^{73}$ KANT, Escritos pré-críticos, 189.

${ }^{74}$ KANT, Escritos pré-críticos, 178.

75 KANT, Escritos pré-críticos, 181.

${ }^{76}$ KANT, Escritos pré-críticos, 182.

77 KANT, Escritos pré-críticos, 176.

78 KANT, Escritos pré-críticos, 184.

${ }^{79}$ KANT, Escritos pré-críticos, 195.
}

800 pensamento místico parece perturbar a filosofia de Kant até mesmo após seus escritos críticos, uma vez que ele dedica Sobre um recentemente enaltecido tom de distinção em Filosofia [1796], um de seus últimos textos escritos, a responder a outro místico, J. G. Schlosser, popular filósofo neoplatônico e cunhado de Goethe, a quem Kant nomeia retoricamente ora por filósofo da visão (visionário), ora por mistagogo (popular intérprete de sonhos), ora por eudaimonista (KANT, 2010, 159), alguém que se guia por um caminho sem qualquer princípio 


\section{A experiência visionária de Swedenborg}

Kant dedica muita atenção à figura visionária de Emanuel Swedenborg ${ }^{81}$ - que por motivo desconhecido é nomeado por Kant como Schwedenberg ${ }^{82}$-, a quem direciona toda a segunda parte dos Sonhos. Kant caracteriza Swedenborg como um vidente que vive em Estocolmo:

Vive, em Estocolmo, um certo Senhor Schwedenberg, sem cargo nem ofício, de sua fortuna bastante considerável. Toda sua ocupação consiste em manter relações bem precisas, como ele mesmo diz, já há mais de vinte anos, com espíritos e almas defuntas, recolher deles notícias do outro mundo e dar-lhes, em contrapartida, algumas notícias do mundo presente, escrever grossos volumes sobre suas descobertas e viagens (...) Ele não é nada reservado com seus segredos, fala disso livremente com qualquer um, parece inteiramente convencido daquilo que conta, sem a menor aparência de fraude montada ou de charlatanice 83 .

Embora Kant o chame ironicamente de seu herói - "legítimo oráculo dos espíritos" (KANT, 2005, p. 203) por ser ele o "arquivisionário entre todos os visionários, assim ele é também seguramente o arquifantasista entre todos os fantasistas" 84 -, ao vidente sueco não é atribuído o papel de charlatão. Pelo contrário, Kant entende que a visão psíquica e interior de Swedenborg merece significativa atenção.

0 que nos diz Swedenborg de tão intrigante? Primeiramente, em sua Arcana Celestia, ele faz uma descrição tão misteriosa e segura da topografia do céu e da natureza dos anjos,

objetivo "da razão que guia moralmente a alma" (KANT, 2010, 162). 0 que está em disputa aqui é a própria filosofia, ou melhor, a base epistemológica que diferencia o pensamento místico da filosofia crítica. Para a mística, não apenas o sentimento, mas também a poesia e a música são capazes de fundamentar o conhecimento. Já para Kant, "a experiência interior e o sentimento (que em si é empírico e com isso contingente) são excitados unicamente pela voz da razão, que fala a todos clara e distintamente e é apta a um conhecimento científico" (KANT, 2010, 164), moral e prosaico-conceitual. Schlosser, ao contrário, vem propor uma filosofia em tonalidade poético-musical, que pudesse substituir o trabalho do conceito pelo sentimento do senso comum no mundo. Nessa esteira, a filosofia não deveria levar-nos tanto para elevadas esferas, mas sim a pesquisar "o funcionamento da vida em nós ou, se se preferir, as divagações visionárias sobre uma secreta ordem musical do mundo" (MADRID, 2012, 61). Essa filosofia musical traria em si a potência de afetar o sentimento da vida e modificar o estado do sujeito, mas nunca atinge o nível do reconhecimento no conceito, porque o alvo dela é o movimento anímico, demovendo estados da alma, que ganha poderes de exercer a atividade do médico do corpo, cuidando dele (MADRID, 2012, 62). Schlosser vem falar de uma filosofia do pressentimento, algo que possibilitaria intuir e sentir o suprassensível, "que substitui o indispensável progresso do entendimento por um salto mortale confinante com o delírio, que crê ouvir o murmúrio [Rauschen] do vestido da deusa sabedoria. Kant objetará com determinação no texto [Sobre um recentemente...] diante dos supostos benefícios da intuição intelectual grassados pelo popularphilosoph J. H. Schlosser, o tom orgulhoso dos frutos - das convicções - obtidos tão por meio do trabalho paciente do conceito quanto da perseverante interpretação da letra" (MADRID, 2012, 66). Vale a nota de que um ano antes da escrita de: Sobre um recentemente..., Schlosser apresentou uma espécie de prontuário filosófico-pedagógico destinado aos jovens, em tom de lhes tirar do caminho, até onde fosse possível, os perigos do um pensamento crítico kantiano (MADRID, 2012, 66).

81 Como consta em Cunha $(2013,84)$ : "Emanuel Swedenborg foi cientista e homem de estado na Suécia. Em 1745 revelou o seu verdadeiro dom descrito como a capacidade de se comunicar com o mundo dos espíritos. Este dom sublime permitiu-lhe desvendar o sentido intrínseco das coisas do mundo. Swedenborg, assim, assumiu o compromisso de divulgar o sentido oculto contido nas Sagradas Escrituras e revelou muito desses segredos em seu tratado Arcana Coelestia".

82 KANT, Escritos pré-críticos, 191.

83 KANT, Escritos pré-críticos, 191.

${ }^{84}$ KANT, Escritos pré-críticos, 192. 
que é como se estivesse descrevendo uma de nossas cidades. Não obstante, os anjos, diferente dos homens, não conhecem a noção de tempo e de espaço, isto é, não se orientam cronológica e historicamente por dias, meses e anos; ontem, hoje e amanhã. Os anjos, tampouco, se localizam por distâncias espaciais. "Quando nos ouvem falar em tempos, os anjos que nos acompanham (pois os anjos sempre acompanham os homens) entendem estados" 85 e, como tal, comunicam-se com os homens alterando-lhes os estados de consciência. "No seu mundo, que não é natural, porém espiritual, os movimentos acontecem mediante modificações de estado, e não através de deslocamentos espaciais. Para um anjo não existem distâncias a serem transpostas" 86 e, portanto, não se pode estabelecer conexões com eles através de nossa noção habitual de tempo e espaço, mas sim por intensidades, operadas pela força intuitiva em nós.

Os anjos apresentam-se aos homens de acordo ao laço de desejos que tornam cada manifestação mais ou menos intensa.

Por exemplo, se sentem desejo por alguém, imediatamente lhe ficam visíveis, pois se colocam através deste desejo em seu estado. Se sentem repulsa, logo se afastam, pois se afastam do seu estado. Da mesma forma, se vão de um paradeiro a outro em meio a um jardim ou a um átrio, chegam mais depressa caso anseiem por isso, chegam mais devagar quando o anseio é menor ${ }^{87}$.

Ora, é preciso demarcar que os anjos como descritos pelo vidente sueco não são anjos entediados ou repetitivos,

Talvez porque não estejam apenas observando o mundo; estão constantemente tornando-se outra coisa, sempre metidos em devir-algumacoisa, em devir-algum-estado, em devir-algum-estado-de-alguém-ou-dealguma-coisa. Não são anjos metafísicos, especulativos, olheiros, eternitários. Não são anjos-filósofos, mas anjos crianças. Vivem as oscilações, os bruscos afastamentos e aproximações, as intensidades, uma disritmia, uma cronoilógica, descontinuidades, intempestividades, estados: devires bem próximos da loucura ${ }^{88}$.

Uma vez que os anjos narrados por Swedenborg são alheios à história, à sucessão cronológica e ao encadeamento temporal, estão sujeitos a transformações bruscas, deslocamentos repentinos e mudanças inusitadas de estados e, por isso, exigem certa comunicação psicótica, pouco compreensível em termos de categorias intelectivas e por isso facilmente julgadas, "diagnosticáveis" por aqueles que se arrogam pela razão ${ }^{89}$.

Dessa maneira, o elemento central que me interessa a resgatar no pensamento visionário de Swedenborg é o de que ele retoma a ideia de corpo mágico, local de intensidades e possibilidade de comunicação com deuses, esferas celestes e astros do Universo sem sequer sair do lugar. Essa compreensão de corpo mágico, lugar de comunicação entre órgãos e espírito, viabiliza exercícios de projeção astral que teriam permitido a Swedenborg usar seus órgãos para estabelecer contatos astrais.

Tal interface entre psique e corpo é que foi silenciada pela mecânica cartesiana e, igualmente, descrita e desqualificada pelo próprio Kant:

\footnotetext{
85 PELBART, A nau do tempo-rei, 73.

86 PELBART, A nau do tempo-rei, 74.

87 PELBART, A nau do tempo-rei, 74.

88 PELBART, A nau do tempo-rei, 75.

${ }^{89}$ Como afirma Pelbart: "Não nos deveria surpreender o fato de que Karl Jaspers tenha utilizado também estas descrições de angelologia sueca para formular seu diagnóstico psiquiátrico sobre Swedenborg, colocando-o lado a lado de outros três gênios loucos, Van Gogh, Holderlin e Strindberg" (PELBART, 1993, p. 74).
} 
As diversas forças e propriedades da alma estão em simpatia com os órgãos do corpo subordinados a seu governo. 0 todo do homem externo corresponde, portanto, ao todo do homem interno, e, por isso, se um influxo espiritual notável do mundo invisível atinge preferencialmente uma ou outra destas forças de sua alma, ele sente também harmonicamente a presença aparente desse influxo nos membros correspondentes de seu homem externo. A isso ele reporta, então, uma grande multiplicidade de sensações de seu corpo, sempre ligadas à contemplação espiritual, cujo absurdo, porém, é tão grande, que não me atrevo a mencionar nenhuma delas ${ }^{90}$.

Ao contrário de uma leitura convencionalmente cristã, Swedenborg vem descrever céu e inferno como espaços derivados de nossa própria interioridade, endossando "o postulado presente no oráculo de Delfos e importante para a tradição gnóstica: 'Conhece-te a ti mesmo e irás conhecer o universo e os deuses'”91. Nessa perspectiva, a subjetividade alia-se à paisagem, o que lhe possibilitou projetar sua consciência de maneira a contemplar as regiões celestes e infernais, descrever outros planetas do sistema solar, referidos por ele como "as outras terras do universo"92, assim como locais e seus respectivos habitantes, de modo detalhado e muito próximo ao que concebemos por real.

Ele fala, assim, de jardins, vastas regiões, de moradias, galerias e arcadas dos espíritos, que veria com seus próprios olhos na mais clara luz, e garante que, tendo falado várias vezes com todos os seus amigos após sua morte, constatou quase sempre, naqueles que morreram recentemente, que eles mal podiam se convencer de ter morrido, porque viam um mundo semelhante à sua volta ${ }^{93}$.

Em suas aventuras mágicas, Swedenborg não parece gozar de faculdades distintas das dos outros humanos, uma vez que, segundo suas declarações, "todos os homens se encontram em ligação igualmente íntima com o mundo dos espíritos, só que não o sentem, e a diferença entre ele e outros consiste apenas em que seu âmago está aberto, dom de que fala sempre com respeito"94. Ou seja, quando mais evocamos pelos anjos mais sentimos seus estados presentes em nós.

A abertura do âmago às forças astrais ocorre pela fértil imaginação e pela intuição e será justamente esse o ponto problemático para Kant, uma vez que elas permitem ao homem ter experiências para além da razão, categoria que somente opera em termos de "comparação segundo a identidade e a contradição" 95 . À medida que a magia opera pela inclusão do terceiro excluído - ambientando outras formas de se relacionar com a verdade e a razão que foram historicamente excluídos da lógica clássica justamente por se aproximarem do paradigma onírico, da imaginação e da loucura - ela inviabiliza demonstrar e refutar cientificamente experiências espirituais como viagens astrais, por exemplo. Em essência, uma "fantasia monstruosa e gigantesca" 96 como a comunicação da alma com os órgãos do corpo não permite distinguir aquilo que é verdadeiro do real, no olhar de Kant.

O sobrevoo acerca das intuições de Swedenborg permitem-me arriscar a responder por que a experiência visionária perturba a filosofia ilustrada. Dito em outros termos, a intuição próxima à loucura de Swedenborg convoca Kant a separar a filosofia crítica do sonho visionário por pelo menos dois motivos. 0 primeiro deles é que o filósofo alemão não

\footnotetext{
90 KANT, Escritos pré-críticos, 206-207.

91 FERREIRA, Viagens místico-linguística ao Inferno: Considerações sobre a obra de Jorge Luis Borges e Emmanuel Swedenborg, 284.

92 SWEDENBORG apud FERREIRA, Viagens místico-linguística ao Inferno: Considerações sobre a obra de Jorge Luis Borges e Emmanuel Swedenborg, 283.

93 KANT, Escritos pré-críticos, 206.

${ }^{94}$ KANT, Escritos pré-críticos, 202.

${ }^{95}$ KANT, Escritos pré-críticos, 213.

${ }^{96}$ KANT, Escritos pré-críticos, 207.
} 
consegue refutar o vidente sueco, já que encontra em suas histórias fantasiosas o testemunho de sua própria tese, qual seja, "a possibilidade de transpor aquilo que se localiza no mundo do supra-sensível para o mundo da sensibilidade com a utilização das estruturas espaçotemporal (até aqui não entendidas como formas puras da intuição sensível)"97, proximidade essa que implicaria reformular todo o projeto crítico para que seu pensamento não fosse confundido com o esotérico.

O segundo motivo é que o pensamento visionário vem mostrar que as intensidades operadas pela intuição transcende às estruturas espaço-temporais utilizadas pela sensibilidade e pelo intelecto, o que colocaria em xeque a empiria como estatuto do conhecimento científico e humano. Uma vez que a experiência empírica será a base para se impor limites ao conhecimento daquilo que pode ser abarcado pelos sentidos na forma espaço-temporal, o pensamento visionário tanto migra para a dimensão de intensidades $e$ mudanças de estados, como utiliza o espaço e o tempo para abranger seres que não se enquadram dessa maneira, o que implica inferir a existência de formas de percepção e de existência independentes das categorias a priori de tempo e espaço pela qual a razão e o intelecto são ancorados.

Exercitar a intuição insinua pensarmos também para além da crítica, que entende a caracterização do tempo e do espaço como estruturas que só podem ser aplicadas ao sensível e fecundam, assim, os limites do conhecimento atrelados à significação humana. Dessa maneira, a experiência visionária dispensaria a condição prévia da realidade humana pela qual estamos confinados para se abrir claramente enquanto força criadora para outras realidades, que podem brotar pela e na imaginação do ente através de sua força intuitiva, o que implicaria a construção de outras bases epistemológicas que conduziriam a experiências éticas e políticas diferentes das quais temos trilhado antropologicamente no presente.

0 jovem Foucault parece intuir bem esse processo. Não à toa ele recomenda que despertar do sono antropológico flertaria com uma descida aos infernos ${ }^{98}$, umbral em que práticas de cura do corpo e da alma (psique) não se guiavam pelo estatuto científico. Inferno "carrega o teor do documento proibido, inacessível, mas sobretudo esquecido e raro"99, que permitiria despertar o sono dos justos do humanismo ocidental, motivo esse que leva as pesquisas históricas foucaultianas a tecerem uma bricolagem entre arquivos oficiais como manuais ou tratados de medicina, mas também diários de asilos, ordenanças institucionais, grimórios e manuais de magia, correspondências, documentos biográficos, obras de arte e outros arquivos mortos.

Dessa maneira, nos textos protoarqueológicos, Foucault torna visível a psique e o inconsciente como objetos que transcendem o humano e a ciência, movimento que permite mostrar a limitação da psicologia para tratar de tais temáticas, espécie de prestação de contas sobre a escolha de sua racionalidade científica.

A psicologia nasceu quando o materialismo definiu a distância que a teologia havia instaurado entre o homem e o homem (...). A 'teologia', conforme visto, implicava a busca da felicidade nos 'tesouros depositados nos céus'; a 'psicologia se torna possível quando, ao invés do homem se dirigir aos 'tesouros celestes', as relações descem à terra, entre o 'homem e o homem'100.

Tomo nota de que "a pesquisa psicológica, sob as mesmas espécies da desmistificação, não realiza nada mais do que um exorcismo, uma extradição de demônios" (FOUCAULT apud

\footnotetext{
97 GIROTTI, Kant e os 'Sonhos de um Visionário': um escrito pré-crítico de cunho crítico?, 165.

${ }_{98}$ Como sugere Miotto $(2011,42)$ : “A 'descida aos infernos', particularmente, é a figura que permanece entre $L a$ Recherche Scientifique et la Psychologie e a Tese Principal [História da Loucura], portanto no silêncio entre o fim do texto de 1957 e a pesquisa histórica realizada em Upsala".

${ }_{99}^{9}$ MIOTTO, O Problema Antropológico em Michel Foucault, 206.

100 MIOTTO, O Problema Antropológico em Michel Foucault, 204.
} 
MIOTT0, 2011, p. 196), ao passo que viajar aos infernos nesse dossiê significa tornar visível uma investigação que toma por margem a heresia de um modelo científico, antropológico e humanista, reconvidando a angeologia (d)e Swedenborg como forma de saber demonizada, procedimento onde o humano não ocupa o lugar de centro, mas é problematizado enquanto análise de sua própria constituição limitada entre tempo e espaço histórico e cronológico, regido pelas continuidades discursivas e racionais. Viajar aos infernos aqui não se trata de empregar um modelo presente para julgar o passado, mas sim de investigar um passado histórico do qual derivou o nosso presente, que poderia ter sido de outra maneira; que podemos pensar sobre outras possibilidades escamoteadas pelos "grandes" textos da história da filosofia.

\section{Apontamentos finais: filosofar para além da crítica e do humanismo}

Viajei ao inferno como contribuição para esse dossiê na tentativa de pensar uma ontologia onírica onde o sonho possa se caracterizar como experiência significativa justamente porque não se fecunda a partir de um sujeito fundante - humano - e, com isso, "antecede a própria cesura entre o subjetivo e o objetivo, entre o sujeito e o objeto"101, tempo e espaço. Nesses termos, sonhar é também uma maneira de fazer a experiência de um mundo próprio por parte daquele que sonha, para que novos sentidos da existência não precisem excluir maneiras poéticas, mágicas e visionárias de perceber a realidade. Foi nesse sentido que percebemos certa continuidade entre a visão xamanística de alma na Grécia arcaica como possibilidade de êxtase, transe ou saída de si, à clarividência de Swedenborg, que se comunicava com entes supra-humanos, como anjos e forças celestes, ativando sua clarividência.

Como interface entre filosofia e magia, o sonho abre para a contemporaneidade uma vinculação paradoxal ao legado crítico do iluminismo, em particular a filosofia kantiana. A primeira parte do paradoxo ocorre porque a crítica kantiana possibilita-nos pensar certa concepção do humano que encampe uma ontologia crítica de si-nós mesmos não como uma teoria, doutrina ou corpo permanente de saber acumulado intelectualmente, mas, como sugere Foucault, enquanto "uma atitude, um êthos, uma via filosófica em que a crítica do que somos é simultaneamente análise histórica dos limites que nos são colocados e prova de sua ultrapassagem possível"102. Posto isso, "o Iluminismo não é uma época a ser circunscrita, uma corrente ideológica a ser definida, mas uma exigência ética no cerne do sujeito crítico"103. Tal exigência ética abre espaço para pensarmos a crítica como esforço ascético necessário desde o exame de nós mesmos, como possibilidade de alterar nossos estados de consciência como portal intuitivo.

Nesse registro, a crítica oferece-nos pouco em termos de tomada de consciência humana, mas implica uma atitude experimental como o trabalho sobre nossos limites e possibilidades enquanto deriva para nos transformarmos em outra coisa, "trabalho paciente que dá forma à impaciência da liberdade"104. A maioridade kantiana é bem-vinda, se referida como uma coragem de verdade do sujeito em se pensar por seu próprio nome, estabelecendo consigo mesmo seus processos de autoformação e transformação, "sem a necessidade de recitar um livro; ser capaz de fazer escolhas de vida sem a tutela de um diretor de consciência; dar-se regras de saúde e de boa existência sem seguir cegamente as prescrições de um

\footnotetext{
101 NALLI, Possibilidades e limites da cura nos textos protoarqueológicos de Michel Foucault, 11.

102 FOUCAULT, Ditos e Escritos II, 351.

103 GROS, Desobedecer, 160.

104 FOUCAULT, Ditos e Escritos II, 351.
} 
médico"105. Nesse sentido, enquanto subjetividades ocidentalizadas somos também profundamente herdeiros do pensamento crítico como importante possibilidade histórica para a consolidação da liberdade institucional e individual em nosso tempo presente e não se trata de escamotear as possibilidades abertas pela crítica em seu curso histórico. Ao menos, um pensador como Foucault entendeu-se como profundo devedor de tais possibilidades e não tornou menor o lugar da crítica no curso de seu pensamento.

Por outro lado, antípoda do paradoxo, será preciso lembrar de todo silenciamento ao pensamento visionário promovido pela filosofia ocidental e, particularmente, pela ilustração kantiana. Na contramão desse silenciamento, ao nos assumirmos como herdeiros das luzes, será preciso também perspectivar o nosso lugar de filhos bastardos, daqueles que desconfiam da narrativa iluminista que fecunda a saída da menoridade calcada na maturidade do Homem esclarecido como o autor que toma em mãos seu próprio destino e se livra das transcendências ilusórias por seu critério de julgamento e tomada de consciência das sombras que o agrilhoam.

Adotando também a nossa herança maldita como filhos legítimos das bruxas e dos videntes queimados, será preciso perspectivar que a crítica se tornou o passatempo favorito do discurso acadêmico e universitário, "um caminho bem balizado rumo à carreira para os iniciantes cujas teses derrubam cada vez mais, na indiferença e na exaustão gerais, as crenças que supostamente nos dominam"106. Na companhia de Otsuka, enquanto acadêmico, sou também tomado pela postura autocrítica de reconhecer que a crítica "tem se mostrado, na maior parte, incapaz de elaborar a experiência presente [...], talvez não seja por estar em crise, mas por estar funcionando muito bem, inteiramente ajustada à lógica gestionária atual"107. Nesses termos, reaprender a cultivar a magia exige que resistamos à capacidade do julgamento crítico como à eminente tarefa política de 'desmistificação' e 'desocultamento' promovida pelo discurso especializado e racional ao qual em não raras vezes se envelopam o psicanalista, o intelectual, o cientista, o filósofo, etc.

A maneira de olhar para tais referências exige uma leitura crítica pensada em termos muito diferentes do julgamento e do valor, mas tomada como exercício de atenção e meditação relacionados aos atos da leitura e da escrita afetiva para a transformação de si. A crítica assim pode ser pensada como um tipo de prática filosófica que reconvide o sonho para dialogar conosco na atualidade, tarefa que venha ampliar o acesso a nossa subjetividade para além do pensamento crítico e do humanismo como paradigma epistemológico e disciplinar pelo qual fomos forma(ta)dos dentro da instituição educativa, especificamente a universitária. Entendo que o diálogo com formas de saberes e práticas depreciadas pela razão, tais como a feitiçaria ou o xamanismo, não representam propriamente a contestação daquilo que se consolidou por pensamento racional, mas o aprofundamento investigativo a tais saberes e práticas possibilitaria a expansão da consciência para percebermos outras maneiras de nos relacionarmos com a questão da verdade e do real, que nos ofereceria outras possibilidades de atitude filosófica, que o próprio Foucault parecia intuir ao guinar o seu pensamento para a espiritualidade antiga, por exemplo.

Nesses termos, a magia parece encontrar na filosofia uma atitude-limite em forma de crítica situada nas fronteiras entre a semelhança e a diferença, entre o si e o outro, "como pesquisa histórica através dos acontecimentos que nos levaram a nos constituir e a nos reconhecer como sujeitos do que fazemos, pensamos, dizemos"108, da mesma maneira que a filosofia encontra na magia a possibilidade de extrapolar os seus próprios limites enquanto arte de existência humana, que retomasse o encantamento e o extraordinário da vida no

\footnotetext{
105 GROS, Desobedecer, 160.

106 STENGERS, No tempo das catástrofes, 103.

107 OTSUKA, Crise da crítica? Crise ou ajustamento?, 33.

108 FOUCAULT, Ditos e escritos II, 348.
} 
tempo presente. Mais precisamente, será preciso aprender a escutar as vozes infames daqueles que habitualmente não tiveram lugar de fala nos regimes estatutários do saber, gesto que sugere uma reflexão radical sobre os modos hegemônicos de pensar para o qual somos formados em nossas instituições educativas.

Trata-se de inventariar um ethos não restrito à consciência, onde a magia pode contribuir para expandirmos a maneira como temos pensado a filosofia no tempo presente. Se entendemos a ética pela relação como diferenciação sobre aquilo que somos, a busca pela transformação de si parece menos complexo do que imaginamos: não reside em Deus, como lido pela tradição dualista e transcendente, tampouco numa vida exterior que não seja essa, mas estaria cravada nas insígnias de nós mesmos, na intuição dispendida pelo corpo que habitamos aqui e agora, como sugeriu Swedenborg. Em suma, convidar na contemporaneidade a experiência visionária incorrida nos processos oníricos para conversar permite colocar em jogo o modelo antropológico e identitário pelo qual se fecundou nossas estruturas de saber e de ser-humano, um exercício para aquém e para além da crítica, pré e pós humanista.

\section{Agradecimento}

Agradeço a Sinésio Ferraz Bueno, espírito amigo de outras passagens, inspirador de partilhas que transcendem a materialidade das palavras e das coisas. Que a estrela te guie em novos ciclos...

\section{Referências}

AGAMBEN, G. Signatura rerum - sobre el método. Córdoba: Adriana Hidalgo Editora, 2009.

CUNHA, B. Sonhos de um Visionário e suas contribuições para a ética de Kant, Cadernos de Filosofia Alemã, São Paulo, n. 22, p. 83 - 106, 2013.

JORGE, M. A. C. Apresentação à edição brasileira. In: DE DALDIS, ARTEMIDORO. Sobre a interpretação dos sonhos. Trad. Eliana Aguiar. Apres. Marco Antonio Coutinho Jorge. Notas: A. J. Festugiere. Rio de Janeiro: Jorge Zahar, 2009.

DODDS, E. R. Os gregos e o irracional. Trad. Paulo Domenech Oneto. São Paulo: Escuta, 2002.

ELIADE, M. Yoga: imortalidade e liberdade. Trad. Teresa de Barros Velloso, Transliteração sânscrita Lia Diskin. São Paulo: Palas Athena, 1996.

FOUCAULT, M. O xamanismo e as técnicas arcaicas do êxtase. Trad. Beatriz Perrone-Moisés e Ivone Castilho Benedetti. São Paulo: Martins Fontes, 2002.

FERREIRA, R. Z. A. Viagens místico-linguística ao Inferno: Considerações sobre a obra de Jorge Luis Borges e Emmanuel Swedenborg. Estação Literária, Londrina, V. 10c, fev, p. 277 - 291, 2013.

FEYERABEND, P. Contra o método. São Paulo: Ed. Unesp, 2003.

FONSECA, M. A.; MUCHAIL, S. T. Apresentação da tradução brasileira. In: FOUCAULT, M. Gênese e estrutura da antropologia de Kant. São Paulo: Loyola, 2011. 
FOUCAUlT, M. História da Sexualidade III: o cuidado de si. Trad. Maria Thereza da Costa Albuquerque. Rev. Técnica de José Augusto Guilhon Albuquerque. Rio de Janeiro: Graal, 1985.

FOUCAULT, M. As palavras e as coisas: uma arqueologia das ciências humanas. Trad. Salma Tannus Muchail. 8. ed. São Paulo: Martins Fontes, 2002.

FOUCAULT, M. Ditos e Escritos I: Problematização do sujeito: psicologia, psiquiatria e psicanálise. Trad. Vera Lucia Avellar Ribeiro; Org. Seleção de Textos Manoel Barros da Motta. 2. ed. Rio de Janeiro: Forense Universitária, 2006b.

FOUCAULT, M. A arqueologia do saber. Trad. Luiz Felipe Baeta Neves. 7. ed. Rio de Janeiro: Forense Universitária, 2008a.

FOUCAULT, M. Ditos e Escritos II. Arqueologia das ciências e história dos sistemas de pensamento. Org. e sel. de Textos Manoel Barros da Motta. Trad. Elisa Monteiro, 2. ed. Rio de Janeiro: Forense Universitária, 2008b.

FOUCAULT, M. A hermenêutica do sujeito: curso dado no Collége de France (1981 - 1982). 3. ed. São Paulo: Martins Fontes, 2010b.

FOUCAUlT, M. A Coragem da verdade. São Paulo: Martins Fontes, 2011a.

FOUCAULT, M. Ditos e Escritos VII. Arte, epistemologia, filosofia e história da medicina. Org e sel. Manoel Barros da Motta, Trad. Vera Lucia Avellar Ribeiro. Rio de Janeiro: Forense Universitária, 2011b.

FOUCAULT, M. Do governo dos vivos: curso no Collège de France (1979 - 1980) Trad. Eduardo Brandão. São Paulo: WMF Martins Fontes, 2014.

FOUCAULT, M. Subjetividade e verdade: Curso no Collège de France (1980 - 1981). Edição estabelecida por Frédéric Gros sob direção de François Edwald e Alessandro Fontana, Trad. Rosemary Costhek Abílio. São Paulo: WMF Martins Fontes, 2016.

FREITAS, A. S. de. Os perigos de uma ontologia política ainda sem cabimento ou o legado éticoespiritual de Michel Foucault, In: REZENDE, H. (org). Michel Foucault: Política, pensamento e ação. Belo Horizonte: Autêntica, 2016.

FREITAS, A. S de. $O$ enigma da revolta. Entrevistas inéditas sobre a Revolução Iraniana, São Paulo: n-1 edições, 2018a.

GERNET, L. Antropología de la Grecia Antigua. Madrid: Taurus, 1984.

GIROTTI, M. T. Kant e os 'Sonhos de um Visionário': um escrito pré-crítico de cunho crítico?, Kínesis, Marília-SP, v. I, n. 02, p. 160-178, out. 2009.

GROS, F. Desobedecer. São Paulo: Ubu, 2018.

KANT, I. Escritos Pré-Críticos. São Paulo: Ed. Unesp, 2005. 
MADRID, N. S. Filosofia, tom e ilusão musical em Kant. Da vivissecção sonora do ânimo à recepção do tom da razão. Trans/Form/Ação, Marília, v. 35, n. 1, p. 47-72, jan./abril, 2012.

MAUSS, M. Sociologia e Antropologia. São Paulo: Cosac \& Naify, 2003.

MIOTTO, M. L. O Problema Antropológico em Michel Foucault. 2011. 235 f. Tese (Doutorado em Filosofia) - Programa de Pós-Graduação em Filosofia, Universidade Federal de São Carlos, São Carlos, 2011.

NALLI, M. Possibilidades e limites da cura nos textos protoarqueológicos de Michel Foucault. Trans/Form/Ação, Marilia, v. 34, n. 2, p. 155-177, 2011.

OTSUKA, E. T. Crise da crítica? Crise ou ajustamento? Revista Cult, São Paulo, ano 16, n. 182, p. 30 - 33, ago. 2013.

PELBART, P. P. A nau do tempo-rei: sete ensaios sobre o tempo da loucura. Rio de Janeiro: Imago Ed. 1993.

PEREnCINI, T. B. Arqueologia e Magia. Cadernos de Ética e Fillosofia Política, São Paulo, v. 2, n. 35, p. 232-249, 2019.

PERENCINI, T. B. Educação, filosofia e magia: uma anarqueologia do cuidado de si entre o daimon e os sonhos. 2020. 269p. Tese (Doutorado) - Programa de Pós-Graduação em Educação, Universidade Estadual Paulista (Unesp) Faculdade de Filosofia e Ciências, Marília, 2020.

RIBEIRO, S. O oráculo da noite. A história e a ciência do sonho, 1aa ed, São Paulo: Companhia da Letras, 2019.

STENGERS, I. No tempo das catástrofes - resistir à barbárie que se aproxima, Trad. Eloisa Araújo Ribeiro, São Paulo: Cosac Naify, 2015.

TERRA, R. R. Foucault leitor de Kant: da antropologia à ontologia do presente. Analytica, v. 2, no 1, Rio de Janeiro, 1997.

VEYNE, P. Foucault: seu pensamento, sua pessoa. Trad. Marcelo Jacques de Morais, Rio de Janeiro: Civilização Brasileira, 2011. 